\title{
Self-management needs of breast cancer survivors after treatment: Results from a focus group interview
}

\author{
Soo Hyun Kim, RN, PhD \\ Department of Nursing, Inha University, Incheon, South Korea
}

\section{INTRODUCTION}

Following increases in the rate of early detection of breast cancer and improvements in its treatment, approximately $90 \%$ of patients now survive at least 5 years after diagnosis, and $80 \%$ survive 10 years. Breast cancer survivors (BCSs) face many challenges during their survivorship period. They should receive regular check-ups to screen for recurrence, manage long-term and late effects, and encourage a healthy lifestyle that reduces the risk of a second cancer or comorbidity. Given the importance of survivorship care planning, the self-management (SM) support program has been suggested as a promising model of cancer survivorship care. SM support refers to support of an individual's ability to manage the symptoms, treatment, and physical, psychosocial, and lifestyle changes inherent in living with a chronic condition. SM support seeks to empower individuals to cope with disease by enhancing their confidence in dealing with their chronic conditions. To provide SM support program effectively, we should first understand what the survivors know about their SM tasks, what skills they need to acquire, and the kind of support they need the most. However, few previous studies of BCSs supportive care needs focused on SM needs after treatment.

\section{PURPOSE OF THIS STUDY}

This study aimed to explore the SM needs of post-treatment BCSs using focus group interviews.

\section{METHODS}

- Study Design : A qualitative research using focus group interviews

* Participants

- Inclusion criteria

- Women aged over 18 years

- Diagnosed with stage I-III breast cancer

- Received and finished their primary breast cancer treatment (surgery, chemotherapy, or radiation),

- Were able to speak and read Korean

- Exclusion criteria

- Had a recurrence or metastasis

- Had a severe cognitive impairment

* Interview Questions

1. After breast cancer treatment, what was your biggest challenge regarding SM?

2. After breast cancer treatment, please tell us what you think is important about SM for recovery and return to daily life.

3. After breast cancer treatment, please tell us what kind of knowledge and skills you need in order to be effective at SM.

4. What helped and interfered with SM after breast cancer treatment?

* Data analysis : Conventional content analysis

\section{RESULTS}

* Characteristics of the participants

We interviewed a focus group of 20 BCSs who underwent cancer therapy at a university hospital in South Korea. The mean age of the participants was 56.0 years $(S D=6.4)$. Sixty percent $(n=12)$ were married. The mean time since diagnosis was 3.4 years $(S D=1.3)$. All participants received surgery and chemotherapy, and $85 \%$ had undergone radiation therapy.

* Themes, sub-themes, and categories of SM needs

The focus group interviews revealed 10 subthemes that we organized into five themes about the post-treatment SM needs of BCSs: 1) symptom management needs, 2) emotional management needs, 3) information acquisition needs, 4) need for a relationship with healthcare providers, and 5) adaptation needs.

\begin{tabular}{|c|c|c|}
\hline Themes & Sub-themes & Categories \\
\hline $\begin{array}{l}\text { Symptom } \\
\text { management } \\
\text { needs }\end{array}$ & $\begin{array}{l}\cdot \text { Knowledge and skills to } \\
\text { manage symptoms }\end{array}$ & $\begin{array}{l}\cdot \text { Indigestion/anorexia } \\
\cdot \text { Peripheral neuropathy } \\
\cdot \text { Energy depletion } \\
\cdot \text { Insomnia } \\
\cdot \text { Sensory problems }\end{array}$ \\
\hline \multirow[t]{2}{*}{$\begin{array}{l}\text { Emotional } \\
\text { management } \\
\text { needs }\end{array}$} & $\begin{array}{l}\text { - Skills to manage emotional } \\
\text { problems }\end{array}$ & $\begin{array}{l}\cdot \text { Fear of recurrence } \\
\cdot \text { Depression } \\
\text { - Anxiety }\end{array}$ \\
\hline & - Mental health service & \\
\hline $\begin{array}{l}\text { Information } \\
\text { acquisition } \\
\text { needs }\end{array}$ & $\begin{array}{l}\text { - Up-to-date and in-depth } \\
\text { information about disease } \\
\text { management } \\
\text { - Specific information about } \\
\text { lifestyle management }\end{array}$ & \\
\hline $\begin{array}{l}\text { Needs for a } \\
\text { relationship with } \\
\text { health care } \\
\text { providers }\end{array}$ & $\begin{array}{l}\text { - Patient-centered care } \\
\text { - Effective communication skill } \\
\text { - To be empowered }\end{array}$ & \\
\hline \multirow[t]{2}{*}{$\begin{array}{l}\text { Adaptation } \\
\text { needs }\end{array}$} & - Skills to adapt to changes & $\begin{array}{l}\cdot \text { Body image change } \\
\cdot \text { Lifestyle change } \\
\cdot \text { Role change }\end{array}$ \\
\hline & - Building self-confidence & \\
\hline
\end{tabular}

\section{CONCLUSIONS}

Our findings can contribute to the development of breast cancer survivorship care plans by emphasizing post-treatment SM. Future SM support intervention for BCSs after treatment should focus on training SM skills, enhancing the survivor-provider relationship, and building survivor self-confidence.

\section{ACKNOWLEDGEMENTS}

This paper was supported by Basic Science Research Program through the National Research Foundation of Korea funded by the Ministry of Education (Grant number: 2016R1D1A1B04932171). 